E International

\title{
Factoring Sustainable Development into Project Appraisal
}

A French view

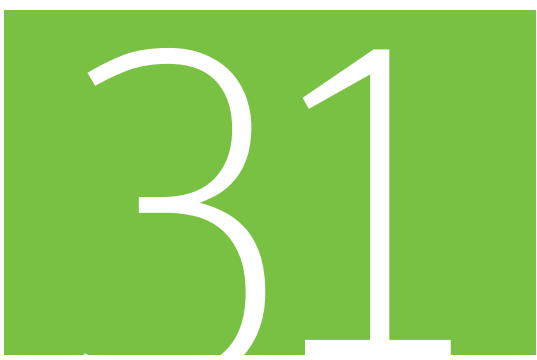

Discussion Paper 2013 • 31

Emile Quinet

Ecole Nationale des Ponts et Chaussées, Paris, France 



\title{
FInternational Transport Forum
}

\section{Factoring sustainable development into project appraisal: a French view}

\author{
Discussion Paper No. 2013-31
}

Prepared for the 1st Session of the OECD/ITF Working Group on Assessment of Policies for Long-term Transition to Sustainable Transport

12-13 December 2013

\section{Emile QUINET}

École Nationale des Ponts et Chaussées

Paris

October 2013 
The International Transport Forum at the OECD is an intergovernmental organisation with 54 member countries. It acts as a strategic think-tank, with the objective of helping shape the transport policy agenda on a global level and ensuring that it contributes to economic growth, environmental protection, social inclusion and the preservation of human life and well-being. The International Transport Forum organises an annual summit of Ministers along with leading representatives from industry, civil society and academia.

The International Transport Forum was created under a Declaration issued by the Council of Ministers of the ECMT (European Conference of Ministers of Transport) at its Ministerial Session in May 2006 under the legal authority of the Protocol of the ECMT, signed in Brussels on 17 October 1953, and legal instruments of the OECD.

The Members of the Forum are: Albania, Armenia, Australia, Austria, Azerbaijan, Belarus, Belgium, Bosnia and Herzegovina, Bulgaria, Canada, Chile, People's Republic of China, Croatia, Czech Republic, Denmark, Estonia, Finland, France, Former Yugoslav Republic of Macedonia, Georgia, Germany, Greece, Hungary, Iceland, India, Ireland, Italy, Japan, Korea, Latvia, Liechtenstein, Lithuania, Luxembourg, Malta, Mexico, Republic of Moldova, Montenegro, the Netherlands, New Zealand, Norway, Poland, Portugal, Romania, Russian Federation, Serbia, Slovak Republic, Slovenia, Spain, Sweden, Switzerland, Turkey, Ukraine, United Kingdom and United States.

The International Transport Forum's Research Centre gathers statistics and conducts co-operative research programmes addressing all modes of transport. I ts findings are widely disseminated and support policymaking in Member countries as well as contributing to the annual summit.

\section{Discussion Papers}

The International Transport Forum's Discussion Paper Series makes economic research, commissioned or carried out at its Research Centre, available to researchers and practitioners. The aim is to contribute to the understanding of the transport sector and to provide inputs to transport policy design.

ITF Discussion Papers should not be reported as representing the official views of the ITF or of its member countries. The opinions expressed and arguments employed are those of the authors.

Discussion Papers describe preliminary results or research in progress by the author(s) and are published to stimulate discussion on a broad range of issues on which the ITF works. Comments on Discussion Papers are welcomed, and may be sent to: International Transport Forum/OECD, 2 rue André-Pascal, 75775 Paris Cedex 16, France.

For further information on the Discussion Papers and other JTRC activities, please email: itf.contact@oecd.org

The Discussion Papers can be downloaded from:

www. internationaltransportforum. org/jtrc/DiscussionPapers/jtrcpapers.html

The International Transport Forum's website is at: www. internationaltransportforum.org

This document and any map included herein are without prejudice to the status of or sovereignty over any territory, to the delimitation of international frontiers and boundaries and to the name of any territory, city or area. 


\section{TABLE OF CONTENTS}

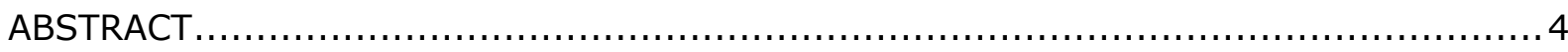

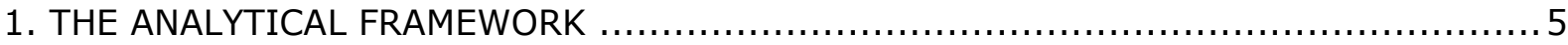

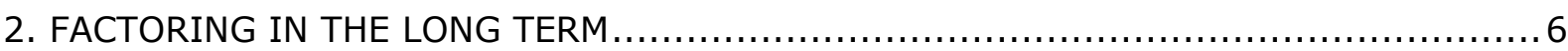

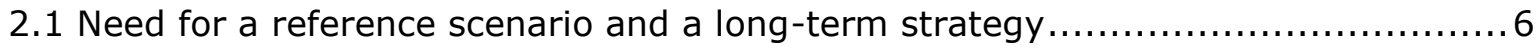

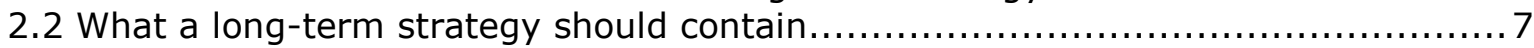

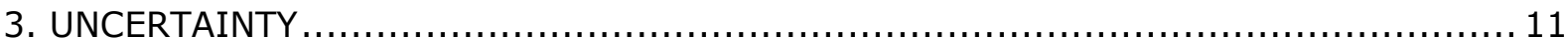

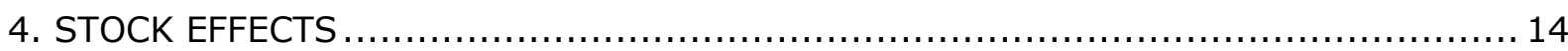

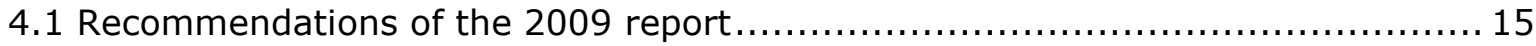

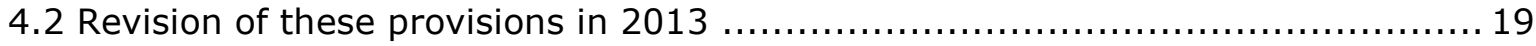

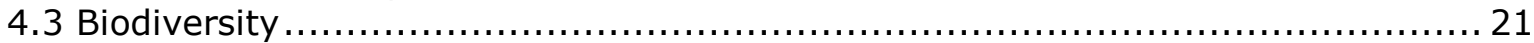

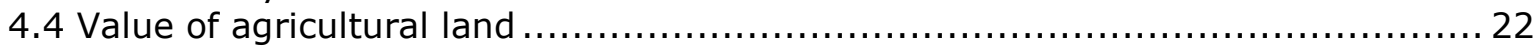

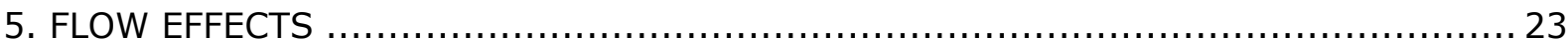

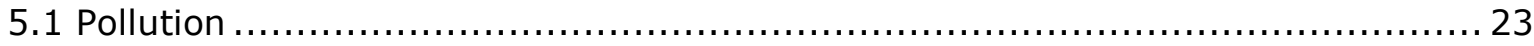

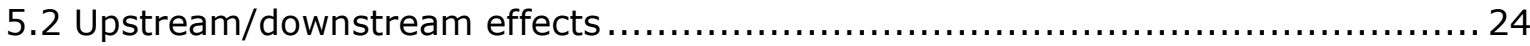

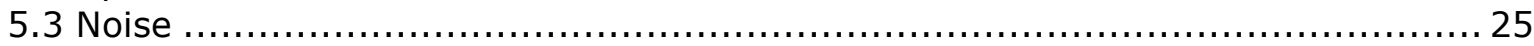

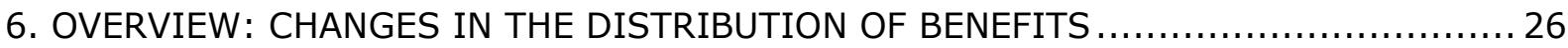

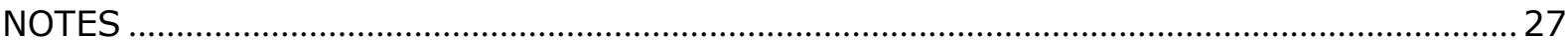

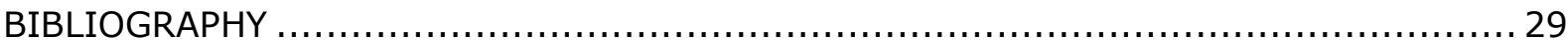

Paris, October 2013 


\begin{abstract}
Factoring sustainable development into the appraisal of investment projects is a topical issue at both the analytical and the decision-making level. In the area of analysis, we find numerous studies and research projects devoted to the assessment of environmental damage and its translation into monetary terms. The analysis concerns both "flow" damage such as pollution and noise, and "stock" damage with long-term cumulative effect, such as global warming and the reduction of biodiversity. In the area of decisionmaking, efforts are being undertaken in many countries to achieve better integration of these concerns in project appraisal and the related cost-benefit analysis. France is no exception: a working party recently set up to revise the methodology for appraising public investment projects has just completed its deliberations. It paid close attention to considerations of sustainable development and the factoring of the long term, and the present paper is based largely on its recommendations. In what follows, we shall endeavour to analyse those recommendations in the light of scientific knowledge and place them in the French institutional and politico-administrative context.

The present paper begins with an overall presentation of the working party's deliberations. It goes on to discuss factoring the long term and one of its key characteristics, uncertainty. That is followed by a discussion of the two major aspects of stock effects, namely global warming - including the issue of carbon cost - and biodiversity. Finally, the paper discusses flow effects - the classical effects of air pollution and noise - and numerous other effects that are less clearly defined. It concludes with an overview of the impact of the new provisions on the choice of projects.
\end{abstract}




\section{THE ANALYTICAL FRAMEWORK}

France has a long tradition with regard to the appraisal of public investment. A series of commissions were appointed by the bodies responsible for economic evaluation - the Commissariat général du Plan (National Economic Planning Agency), the Centre d'analyse stratégique (Centre for Strategic Analysis) and, most recently, the Commissariat général à la stratégie et à la prospective (National Strategic and Forecasting Agency) - for the purpose of defining and improving appraisal procedures. Their conclusions have been translated into instructions and directives issued by the competent administrative bodies. Thus, in 1994, a commission established rules embedding project appraisal firmly in the doctrine of economic calculation. ${ }^{1}$ Other committees dealt subsequently with a number of specific aspects: the evaluation of environmental effects, ${ }^{2}$ determination of the discount rate ${ }^{3}$ the collective value of carbon value, ${ }^{4}$ biodiversity ${ }^{5}$ and risk assessment. ${ }^{6}$

In 2012, it was decided that all these reports, the earliest of which were almost 20 years old, needed to be updated in the light of new knowledge in the field, the changing economic context and current issues, among which considerations of sustainable development are, of course, increasingly important. The working party set up for that purpose, on whose deliberations the present paper is based, recently submitted its report under the title "Socio-Economic Evaluation of Public Investment". ${ }^{7}$ Its proposals are the result of reasoned critical analysis of the existing literature, the statistical evaluations to which that literature has given rise in France and abroad, and certain studies and research undertaken in the framework of the working party's specific remit. The report begins by updating the unit values used in economic calculation. It proposes enhancing the traditional calculation method by including what are generally called "wider economic effects". It defines criteria for the selection and hierarchical ordering of projects that incorporate long-term considerations and risk assessment. Finally, it makes proposals for improving the management of studies and integrating them in the decision-making process. We shall be concerned here with those aspects of the report which relate to sustainable development, i.e. its proposals concerning the long term and risk assessment, and the modalities for factoring environmental effects. 


\section{FACTORING IN THE LONG TERM}

\subsection{Need for a reference scenario and a long-term strategy}

Transport investments have a notoriously long lifetime. Almost all of them last for more than a century. In view of the long gestation period that follows an investment decision, usually 10 years or more, it is clear that the benefits expected from an investment decided on today will appear only around 2025, and will extend until 2150 at the least. While discounting helps to reduce the impact of the distant future, simple calculations show that everything which occurs before, say, 200 years have passed has a nonnegligible impact on the economic balance sheet, especially as discount rates generally tend to fall. It is therefore important to extend the horizon currently adopted in France to 50 years. That would simply follow the trend seen in the recommendations of other countries, which a few dozen years ago adopted horizons of 20 to 30 years, whereas they are now rarely less than 50 years. In line with that reasoning, the report recommends performing profitability calculations up to 2070 , and adopting beyond that year a residual value corresponding to 50 years of the last year's benefits, which are assumed to remain stable from that year on.

But how can economic calculations be made that cover such a long period? In answering that question, a basic feature of project appraisal must be borne in mind, i.e. the fact that projects are carried out in the margins (a situation always assumed in the case of small projects) of a growth trajectory defined by price and quantity chronologies, lifestyles and utilities.

A number of things follow from this. First, it is likely that, by the end of the time periods envisaged, around a hundred years at least, if the risk of natural disasters about which there is a relatively broad consensus in the Intergovernmental Panel on Climate Change (IPCC) is to be avoided, we shall have to have considerably reduced our greenhouse gas emissions. We shall also have to undertake, in conditions yet to be defined, the revision of our energy policy. Furthermore, we shall probably have to reduce land artificialisation, or suffer the consequences of the reduction of biodiversity. While we have an idea of the solutions to be adopted for the next 15 to 20 years, the prospects for more distant horizons, from 2060 to 2080, are much more open. Different approaches are possible, and their consequences for infrastructure policy are easy to see: for example, in the transport sector, a reduction in mobility, a massive mode shift, a change in spatial organisation such as to reduce travel distances, technological advances more or less related to lower vehicle performance, or finally, and more probably, a yet-to-bedetermined combination of these different approaches. And the profitability of any specific project can be very different, of course, depending on the approach adopted: how can we evaluate the benefit from a motorway when we don't know whether, 50 years from now, the traffic it carries will continue to increase or, on the contrary, decline? This shows that project appraisal is impossible in the absence of a strategic framework. It could be dispensed with during the three decades of the post-war boom, when extrapolation from past trends took the place of a strategy. It was still possible to do without it up to the end of the last century, despite the slow-down in growth and the 
recurrent crises. One simply assumed that growth was a little less strong and more uncertain. Now, however, definition of a long-term strategic framework can no longer be deferred. And, clearly, the strategy in question is only partly dependent on infrastructure policy, which is often more a consequence of that strategy than a component.

\subsection{What a long-term strategy should contain}

A strategy of this kind must be based primarily on prospective growth, both volumetric and structural, and on demographic and lifestyle changes. It must also take account of expected technological developments and, of course, the implementation of public policy measures, especially those embodying our environmental and energy commitments to future generations. All of which requires price and quantity chronologies and data concerning regulations. It is clear that, apart from the macro-economy (GDP, etc.), the most important parameters relate to the energy sector (price of oil, shadow price and possible taxation of carbon), spatial planning (regulation and taxation of urban development) and, of course, transport (taxation, vehicle and traffic regulations). 


\section{Figure 1. Reference trajectories for project appraisal}

(horizon: $2012-2080$ )

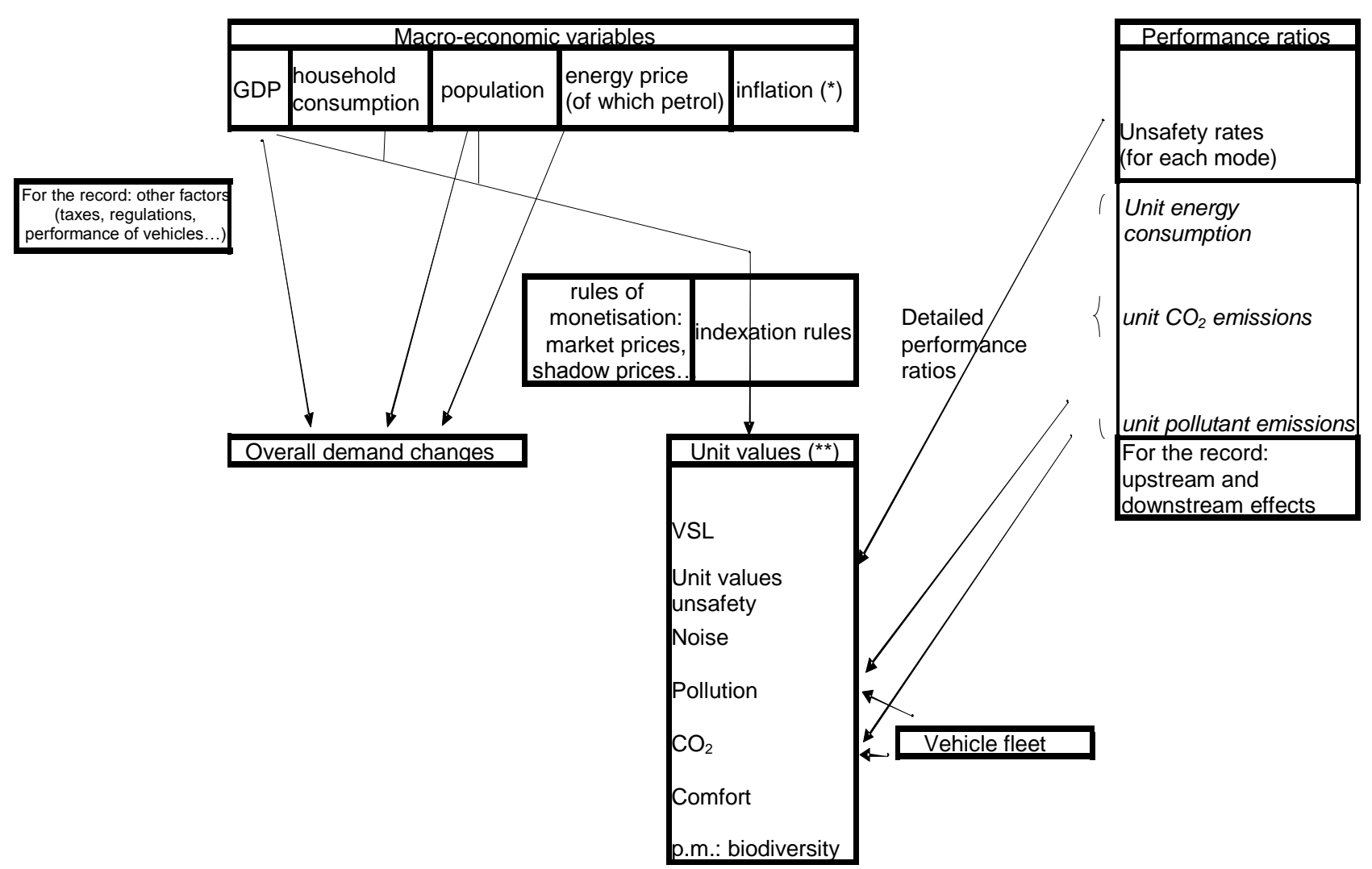

${ }^{*}$ Used for links between socio-economic and financial appraisal

$(* *)$ The factors to use for surplus calculations are provided by the traffic models 
The above diagram, taken from David Meunier's contribution to the report in question, illustrates the modelling that might be envisaged and the input and output data that would be needed to establish an ideal scenario. Many exercises of this type have been conducted, both by official bodies and by individual analysts, so we are spoilt for choice. Let us mention a few recent studies without attempting to be exhaustive, in order to illustrate some general features of the work on the subject.

- At the level of the European institutions, we have first of all the studies undertaken by the Commission, the most important of which are two white papers entitled "European transport policy for 2010: time to decide" (2001) and "Roadmap to a Single European Transport Area - Towards a competitive and resource efficient transport system" (2011). These studies take the year 2050 as the most distant horizon. They begin by pursuing the extrapolation of path trends to its conclusion (the BAU scenario), and then trace the consequences of various scenarios that would make it possible to meet the constraints imposed by international commitments currently in force or deemed desirable.

- In France, several exercises have been undertaken along similar lines. Mention may be made of the ENERDATA study "Comment satisfaire les objectifs internationaux de la France en termes d'émissions de gaz à effet de serre et de pollution transfrontière" [How to meet France's international objectives with regard to greenhouse gas emissions and cross-border pollution] (Prédit, Paris, 2008, B. Château, V. Bagard, Y. Crozet and H.G. Lopez-Ruiz). It sets the horizon at 2050, like the previous work, and uses a model which is centred more on technological developments and the effects of public policies than on macroeconomic consistency. Here, too, the study proceeds by way of scenarios. In addition to a business-as-usual scenario in which the emission targets are not achieved, it sets out two scenarios geared respectively to regulation and technology and to quota and tax mechanisms.

- In 2012, the French Environment and Energy Management Agency (ADEME) produced a paper entitled "Contribution de I'ADEME à l'élaboration de visions énergétiques 2030-2050" [ADEME contribution to the establishment of energy scenarios 2030-50]. While the 2030 scenario is business as usual, the 2050 version is based on energy and environmental targets to be achieved by that date. Compared with the above-mentioned ENERDATA study, the ADEME paper envisages wider-ranging policies, in particular on urban development and construction, but deals with the transport sector in less detail.

- In a paper entitled "Planning Transport Networks for an Uncertain Future: A UK Case Study", delivered at the recent European Transport Conference (ETC 2013), Blaney, Hickford and Preston presented the results obtained by the Infrastructure Transitions Research Consortium (ITRC). This paper too is a study of preestablished scenarios, but it differs from the earlier studies in two respects. The first difference is that it sets the horizon at 2100 . The second is that it takes account of geographical locations, which makes it possible to identify transport links where problems of capacity will arise.

This very small sample of the many studies aimed at elucidating the future environmental and energy transitions shows, above all, the cautious approach to longterm analysis. Like the first three papers mentioned, most studies do not go beyond 2050. Yet 2050 is a very close date, bearing in mind the infrastructure on which 
decisions have to be taken now. By that date, moreover, we shall barely have entered the new world that will follow the energy and environmental transition.

Another issue is the degree to which the hypothesised macro-economic scenarios are dependent on transport infrastructure policy. Most of the studies take that dependence to be of a low order. That seems reasonable in the case of intercity infrastructures, for the following reasons: their financial volume is not large enough to have repercussions and foreclosure effects on other public investments; there are few ways in which infrastructure policy can have an impact economic growth; in the case of intercity links, it is not infrastructure policy that can appreciably influence mode distribution or energy consumption, as seen from Box 1, which shows the weak impact of rail investments on mode distribution; finally, the macro-economic consequences of infrastructures are considered to be weak overall and appear to consist essentially of localisation effects with no great influence on the total volume of activity. The same does not apply to urban infrastructures, which, at least in the long term, have major effects on urban structure and hence on sustainable development. We are familiar with the linked concepts "public transport-dense city" and "private car-urban sprawl", and the well-known consequences in terms of energy consumption and land artificialisation. At the level of urban areas, long-term strategy is strongly influenced by transport infrastructure policy, and the two things must be studied together, not separately.

\section{Box 1. The limited role of infrastructure investments in mode distribution trend}

It is illusory to suppose that investment in modes with low environmental impact, essentially public transport, would suffice in order to achieve a significant reduction in disamentity externalities and alter mode distribution. Infrastructure construction alone cannot dramatically alter mode distribution, as is shown by experience in the development of urban public transport. The increase in passenger numbers in urban public transport resulted largely from an influx of new users who had not travelled previously. A smaller part of the increase consisted of former car users, but the space which they freed up on the roads and streets was occupied by new car drivers seeking to benefit from the better traffic conditions. A further illustration of the inability of infrastructure policy alone to direct user choice effectively is provided by the balance sheet for high-speed rail links in terms of passenger traffic. The key figures in the following table are taken from a fictitious case representing an average situation. They show that the impact of high-speed rail links on the reduction of road traffic is negligible, equivalent to barely one or two years of road traffic increase.

\begin{tabular}{|l|r|r|c|c|}
\hline Traffic in millions of & Before & After & \multicolumn{2}{|c|}{ Difference } \\
\cline { 4 - 5 } passengers per year & & & In absolute figures & As percentage \\
\hline Road & 25.0 & 24.5 & 0.5 & -2 \\
\hline Air & 8.5 & 6.7 & 1.8 & -20 \\
\hline Rail & 9.0 & 13.5 & 4.5 & +50 \\
\hline
\end{tabular}

Source: Quinet, A. and É. Quinet (2012): "La gouvernance des projets d'infrastructure de transports", Revue Transport, February. 
The scenarios tested in these studies are also open to question. Those scenarios, specific to each study, were based on voluntaristic policies conceived by the analysts. While they generally respect the targets set by public authorities, they do not translate decisions on the means to be employed, although they include policy elements which lie in the hands of the decision-makers, such as the percentage reduction in $\mathrm{CO}_{2}$ emissions. One can only wonder about the gap between the targets set and the measures that would be necessary to achieve them, on the one hand, and the trends revealed by the observation of concrete decisions, on the other. Analysis of the European Commission's white papers is illuminating in that respect, as is the gap in France between the target of a fourfold reduction in emissions by 2050 and the public decisions taken, at least so far, with that in view. Dramatic policy changes would be needed in order to meet those targets, which can therefore hardly be considered as firm, unrevisable exogenous data. Nor is it easy to see how that data could be endogenised, i.e. how the behaviour of the public authorities, and adjustment between the targets and the measures adopted to achieve them, could be modelled.

It should be noted that cost-benefit analysis can help in the definition of long-term strategies and reference scenarios but is not sufficient for that purpose, for two reasons. One reason has to do with the nature of long-term strategies, which involve qualitative choices such as those relating to life style. The other has to do with the very nature of cost-benefit analysis, which excels in the comparison of variants. When the variants are too numerous, however, as they are in the case of possible futures, the numerator method is the only way of identifying the optimum variant.

Finally, these scenarios need to be standardised, i.e. the same scenarios must used for all projects to ensure that appraisals of different projects can be compared with each other. Such standardisation can be difficult in terms of political decisions. It will also be difficult when it comes to factoring uncertainty, since long-term strategies cannot be devised without integrating the major risks involved. That is the subject to which we now turn our attention.

\section{UNCERTAINTY}

This section deals with risk proper, i.e. risk that can be probabilised. It can be legitimately argued that certain phenomena involve a more fundamental uncertainty to which it is impossible to assign probabilities. While theoretical methods for dealing with such situations do exist, they are of little operational value. Moreover, one very seldom has no idea at all about the likelihood of such and such an outcome. The following considerations therefore assume a situation in which risk can be probabilised, in line with the approach initiated by the earlier reports referred to above.

There are many sources of risk in project appraisal. The first is the bias of optimism, which is widely documented in the literature. Once that has been eliminated, there are uncertainties about construction and operating costs, as well as the accuracy of the traffic model and its results on entry into service. These types of risk are resolved when the project is put into service. They do not affect the long term and, at least on initial analysis, are not linked to macro-economic trends. We shall not deal with them here, but 
shall concentrate in what follows on long-term risks linked to macro-economic trends, known as systemic risks.

As Box 2 shows, the factoring of system risks is closely connected with the discount system and separation of the classical discount rate into two terms, one representing the risk-free rate and the other the risk premium associated with the project, linked to the correlation between project effects and economic growth. The analysis is similar in form to the method commonly adopted in financial analysis: subject to certain simplifying hypotheses, the corresponding risk effect is measured by the traditional product $\varphi \beta$, where $\varphi$ is the risk premium, a parameter common to all projects, and $\beta$, a projectspecific parameter, measures the link between project benefits and economic activity. Using these notations, the reduction in the benefits of a project is conveniently expressed by applying the rate $r=r_{f}+\varphi \beta$ for each project, where $r$ is the risk-factored discount rate specific to the project, $r_{f}$ is the risk-free rate, and $\varphi \beta$ denotes the project's risk premium. ${ }^{8}$ In line with the Gollier report of 2011, these general considerations inspired the 2013 report, which placed them in an operational framework.

\section{Box 2: Factoring in systemic risk, overall view}

Let there be an investment project such that its construction cost, measured in constant euros, is $I(t)$ if it is completed at time $t$, and its benefits, measured in constant euros at time $t$, are $a(t)$.

Let us first put ourselves in a universe of certainty. The utility of those benefits, and the disutility of the cost, depend on the wealth of the community in the year in which they arise: the poorer the earner, the greater the value of a euro earned. To translate this wealth-dependent variation in the utility derived from a euro, the benefits expressed in constant euros are weighted by a decreasing wealth function. Theoretical considerations, as well as concern for simplicity, lead to adoption of a weighting coefficient with the form $Y(t)^{-\gamma}$, where $\mathrm{Y}$ is a positive coefficient. ${ }^{9}$ Under these conditions, the investment's net present value (NPV), expressed in terms of utility and no longer in euros, and assuming it is put into service in year $T$, is given by the following equation:

$N P V(T)=\int_{T}^{\infty} a(t)^{*} Y(t)^{-\gamma} e^{-\delta t} d t-I(T)^{*} Y(T)^{-\gamma} e^{-\delta T}$

Where $\delta$ is a coefficient representing preference for the present. Let us assume that $Y(t)$ increases at a constant growth rate:

$Y(t)=Y(0) * e^{\mu t}$

or:

$d Y(t)$

$\frac{-1}{Y(t)}=\mu^{*} d t$

We then see that:

$N P V(T)=Y(0)\left\{\int_{T}^{\infty} a(t) * e^{-\mu \gamma-\delta t} d t-I(T) * e^{-\mu \gamma-\delta T}\right\}$

This leads to the usual expression of the discount rate: $r=\delta+\mu \gamma$. 


\begin{abstract}
The problem then is to determine the moment at which the investment should be made, and whether it should be implemented. The solution is well known (Abraham, 1960) and very simple: under relatively unrestrictive conditions, ${ }^{10}$ one should make the investment in the year when the immediate profitability rate equals the discount rate - immediately if the immediate profitability rate is higher than the discount rate - and check that the NPV is positive. This rule assumes that the investment in question is an isolated project unrelated to other projects. It can be extended to apply to connected projects.
\end{abstract}

When we put ourselves in a random universe, the chronologies $a(t), Y(t)$ and $I(t)$ are random. Let us assume they follow Brownian movements defined as follows:

$d \log (Y(t))=\mu d t+\sigma_{1} d w_{1}$
$d \log (a(t))=g d t+\sigma_{2} d w_{2}$
$d \log (I(t))=k d t+\sigma_{3} d w_{3}$

furthermore, the last two processes, mutually independent, are correlated with the first:

$d w_{2}=\rho d w_{1}$

$d w_{3}=\rho_{I} d w_{1}$

It can then be shown ${ }^{11}$ that the NPV resulting from putting the project into service at year 0 is given by the following equation:

$N P V(0)=Y(0)\left\{\int_{T}^{\infty} \underset{(0)}{\infty} * e^{-(r f+B a \varphi) t} d t-I(0) * e^{-(r f+B I \varphi) t}\right\}$

Where:

$r_{f}=\delta+\gamma \mu-0.5 \gamma^{2} \sigma_{1}^{2}$

$\varphi=\gamma \sigma_{1}^{2}$

$\beta_{a}=\rho \frac{\sigma_{2}}{--\sigma_{1}}$

$\beta_{I}=\rho \frac{\sigma_{3}}{---}$

Here we find the risk-free rate $r_{f}$, the risk premium $\varphi$ and $\beta$ coefficients for the regression of benefits and costs on GDP.

The note by B. Lapeyre and É. Quinet annexed to the report on socio-economic evaluation of public investment also gives rules for project selection. They are characterised by the fact that the chronologies are random: no certain NPV can be calculated, only the NPV expected in the event that the investment is put into service at a given date. In these conditions, the decision to implement an investment project is akin to determining the date at which a financial option is exercised. The above-mentioned note gives a precise formula and proposes a simple rule of thumb to the effect that the investment should be made when the immediate profitability rate reaches a certain threshold, for which the value of $4.5 \%$ is recommended. 
Factoring in systemic risk results in a reduction of the value of the benefits expected from investments if those benefits are positively correlated with economic activity, in which case it amplifies the fluctuations of that activity, and vice versa if the correlation is negative, in which case they have a beneficial stabilising effect.

These concepts are well known and commonly used in financial analysis. However, the analogy with financial calculations is essentially a formal one, and although comparison with the financial markets yields useful points of reference, the values of parameters in socio-economic analysis are different from those used in finance; in particular, they cannot be calculated project by project, but only by project category.

The report proposes a risk-free rate of $2.5 \%$, falling progressively to $1.5 \%$ after 2070 , and a risk premium of $2 \%$, rising to $3 \%$ from 2070 . This proposal is based on a combination of market experience, macro-economic considerations and long-term intergenerational concerns. In view of the innovatory nature of these provisions, the report also recommends adopting a single discount rate of $4.5 \%$ in making the calculations during a transitional period used to study feedback from the system, specify project eligibility methods and adjust the parameters deployed by the new system.

The report proposes estimates of initial beta values for the major categories of transport projects. The coefficients lie between 1.0 and 1.5, depending on the transport mode.

Finally, the report deals with the elaboration of project eligibility methods consistent with the new system of discount and systemic risk factoring. The principle (maximisation of net present value) is the same as before, but its insertion in a random framework radically alters the modalities for its application, which are similar in form to financial practice (see Box 2).

\section{STOCK EFFECTS}

\subsection{Carbon}

There are two ways of approaching the issue of carbon cost. The first consists in determining the carbon cost by means of cost-benefit analysis and answers the question: what value optimises the level of carbon emissions? It is the more intellectually satisfying approach and accords with the usual procedure for all monetarisation of environmental effects such as air pollution or noise. It nevertheless involves difficulties of application both technically and with regard to the conclusions to be drawn. On the technical level, those difficulties were reflected in the discussions around the Stern report, which adopted that approach. The other kind of difficulty raised by a cost-benefit procedure has to do with the international nature of the $\mathrm{CO}_{2}$ externality. From the point of view of any particular country, the benefits derived from self-imposed $\mathrm{CO}_{2}$ emission constraints are very limited and would justify only very limited constraints. From a global viewpoint, however, the pertinence of the results for decisions concerning a particular country is questionable unless other countries take concomitant decisions. A global procedure makes proper sense only if considered as a decisional component for an international body like the UN. 
These disadvantages do not arise in the cost-effectiveness procedure followed by the French authorities, which is aimed at determining the shadow carbon price that will enable France to meet its $\mathrm{CO}_{2}$ emission commitments. It should be noted, moreover, that the French commitments largely cover European agreements on the matter and are much more demanding than the agreements concluded at world level. France is faced with three sets of major commitments:

- the Kyoto Protocol, which legally binds the main countries that ratified it to reduce their annual greenhouse gas emissions from 1990 levels over the period 2008-12;

- Europe's commitments to reduce greenhouse gas emissions unilaterally by $20 \%$ from 1990 levels by $2020,{ }^{12}$ or even by $30 \%$ in the event of greater international mobilisation on climate objectives;

- the perspectives announced by the French Government in the Planning Act of 13 July 2005 Establishing Energy Policy Guidelines, which supported the objective of halving global greenhouse gas emissions by 2050, and thus of reducing developed countries' emissions to a quarter of their existing level by that date.

This issue was the subject of an initial overall report in 2009, "La valeur tutélaire du carbone" (A. Quinet), the conclusions of which were revised and updated in 2012 in the report on the socio-economic evaluation of public investment. We shall first describe the approach adopted in 2009, then the revisions made in 2012-13.

\subsection{Recommendations of the 2009 report}

The 2009 report was based, first of all, on evaluations from studies conducted at the time. Table 1, taken from that report, shows a sample of the results provided by official institutions.

The conclusions of the report also took account of various indicators. The first of these were the price signals delivered by the European carbon markets, which exhibited an erratic trend, as shown by the following graph, since they were based on short-term logic and political considerations concerning the extent of the market and its operating rules, much more than on considerations of long-term equilibrium. While those signals now appear totally disconnected from long-term economic logic, in 2005-06, their results delivered estimates of the same order of magnitude as the economic calculations of the time. 
Table 1. Summary of values provided by various official institutions for a tonne of carbon (in 2008 Euros)

\begin{tabular}{|c|c|c|c|c|c|c|}
\hline & France & & European & & ted States (b & \\
\hline & & (DEFRA) & & IGSM & MERGE & MiniCAM \\
\hline 2010 & 32 & 40 (GBP 27.6) & & nd & nd & nd \\
\hline 2020 & 43 & 49 (GBP 33.6) & $40[17-70]$ & 54 & 23 & 20 \\
\hline 2030 & 58 & 60 (GBP 40.9) & 55 [22-70] & 81 & 40 & 36 \\
\hline 2050 & 104 & 88 (GBP 60.8) & 85 [20-180] & 177 & 120 & 98 \\
\hline Target ppme & $\mathrm{Nc}$ & $450-550$ & 450 & $550 *$ (c) & $550 *$ & $550 *$ \\
\hline Discount rate & $8 \%$ & $3.5 \%$ & $4.0 \%$ & & $(3-7 \%)(d)$ & \\
\hline $\begin{array}{l}\text { Increase in carbon } \\
\text { value }\end{array}$ & $3 \%$ & $2.0 \%$ & $2.5 \%(\mathrm{e})$ & $4 \%(f)$ & $5.7 \%$ & $5.4 \%$ \\
\hline
\end{tabular}

Source: Centre d'analyse stratégique.

(a) Handbook on estimation of external costs in the transport sector [produced within the study: Internalisation Measures and Policies for All external Costs of Transport (IMPACT), CE Delft, December 2007].

(b) Values given in dollars are here taken as 2008 values (the report was published in July 2007); in addition, the compatible exchange rate of 1.3 had been adopted (the rate oscillated between 1.2 and 1.3 over $2004-07)$.

(c) 450 ppme for $\mathrm{CO}_{2}$ alone.

(d) In 2005, the Lebègue report pointed to the existence of several reference figures: the General Accounting Office stated that the rate adopted should be the same as that of Treasury Bonds, whose maturation period corresponds to the duration of the projects appraised. In 2005, those rates ranged from $3.5 \%$ to $4 \%$.

(e) and (f) Rates of annual increase recalculated on the basis of the values for 2020 and 2050.

Finally, the report was based on specific modelling exercises using POLES, GEMINI-III and IMACLIM-R. The main characteristics of these three different models are described in Table 2. 
Table 2. Models used in $\mathbf{2 0 0 9}$ to determine the shadow price of carbon

\begin{tabular}{c|l|l|l}
\hline Team & Model & \multicolumn{1}{c}{ Family } & \multicolumn{1}{c}{ Characteristics } \\
\hline LEPII & POLES & $\begin{array}{l}\text { Partial equilibrium } \\
\text { model of the } \\
\text { energy system }\end{array}$ & $\begin{array}{l}\text { By region (47), simulation of energy } \\
\text { demand, technological choices and energy } \\
\text { market equilibrium. }\end{array}$ \\
\hline C-ORDEE & GEMINI E3 & $\begin{array}{l}\text { Computable } \\
\text { general } \\
\text { equilibrium model } \\
\text { of the global } \\
\text { economy }\end{array}$ & $\begin{array}{l}\text { By region (14) and sector (18), description } \\
\text { of resources: production (work, energy, } \\
\text { capital, etc.); imports and jobs: } \\
\text { consumption, exports, investments. } \\
\text { Calculation of international trade in goods } \\
\text { and services and of greenhouse gas } \\
\text { emissions by economic activities. }\end{array}$ \\
\hline CIRED & IMACLIM- \\
R & $\begin{array}{l}\text { Description of growth as a succession of } \\
\text { general annual equilibria, in prices and } \\
\text { equilibrium model } \\
\text { physical quantities } \\
\text { (12 regions/12 sectors), connected by } \\
\text { dynamic sectoral technico-economic } \\
\text { modules (macro-economic dynamics, } \\
\text { development style trends, technological } \\
\text { progress). } \\
\text { Emissions: CO } 2\end{array}$ \\
\hline
\end{tabular}

Each of these models was used in three different scenarios, the main characteristics of which are shown in Table $3^{13}$.

Table 3. Characteristics of the scenarios tested

\begin{tabular}{|l|c|c|l|}
\hline $\begin{array}{l}\text { Scenario of } \\
\text { constraints on } \\
\text { greenhouse gas } \\
\text { emissions }\end{array}$ & $\begin{array}{r}\text { European reduction target (base } \\
\text { year 1990) }\end{array}$ & $\begin{array}{l}\text { International } \\
\text { agreement }\end{array}$ \\
\cline { 2 - 4 } Europe alone scenario & $-20 \%$ & $-60 \%$ & None (own carbon price) \\
\hline Co-ordinated scenario & $-30 \%$ & $-80 \%$ & $\begin{array}{l}\text { Target 550 ppme (single } \\
\text { carbon at global level) }\end{array}$ \\
\hline $\begin{array}{l}\text { Voluntaristic global } \\
\text { scenario }\end{array}$ & & $\begin{array}{l}\text { Target 450 ppme (single } \\
\text { carbon price at global } \\
\text { level) }\end{array}$ \\
\hline
\end{tabular}

Source: Centre d'analyse stratégique.

The main results produced by these models are set out below in Table 4 .

Finally, in addition to the preceding modelling exercises, the carbon value trend over time was investigated theoretically with the use of simple models. The conclusion was that the carbon value should essentially follow a Hotelling-type rule (see Chapter 7 by J. Maurice in the annexes to the 2009 report by A. Quinet). More precisely, theoretical investigation showed that the growth rate should be slightly higher than the discount rate (the difference being linked to the pace of $\mathrm{CO}_{2}$ absorption) until the maximum admissible concentration threshold was reached. Thereafter, it should increase more slowly and then decrease, following a bell-shaped curve, and disappear altogether when natural resources were exhausted. 
Table 4. Simulation results

\begin{tabular}{|c|c|c|c|c|}
\hline & $\begin{array}{c}\text { Europe alone } \\
\text { scenario EU } \\
\text { EUR/tCO }_{2}\end{array}$ & $\begin{array}{c}\text { Co-ordinated } \\
\text { scenario } \\
550 \text { ppme } \\
\text { EUR/tCO } 2\end{array}$ & $\begin{array}{c}\text { Voluntaristic } \\
\text { global } \\
\text { scenario } \\
450 \text { ppme } \\
\text { EUR/tCO }\end{array}$ & $\begin{array}{l}\text { Oil price } \\
\text { USD/b }\end{array}$ \\
\hline \multicolumn{5}{|l|}{ In 2010} \\
\hline POLES & 10 & & & \\
\hline GEMINI-E3 & 1 & & & \\
\hline IMACLIM-R & 45 & & & \\
\hline Average & 19 & & & \\
\hline $\begin{array}{l}\text { Boiteux shadow } \\
\text { price }\end{array}$ & 32 & & & \\
\hline \multicolumn{5}{|l|}{ In 2020} \\
\hline POLES & 26 & 9 & 16 & 79 \\
\hline GEMINI-E3 & 25 & 4 & 13 & 57 \\
\hline IMACLIM-R & 95 & 30 & 100 & 93 \\
\hline Average & 49 & 14 & 43 & 76 \\
\hline $\begin{array}{l}\text { Boiteux shadow } \\
\text { price }\end{array}$ & \multicolumn{3}{|c|}{43} & 41 \\
\hline \multicolumn{5}{|l|}{ In 2030} \\
\hline POLES & 97 & 23 & 57 & 96 \\
\hline GEMINI-E3 & 58 & 10 & 42 & 62 \\
\hline IMACLIM-R & 150 & 55 & 160 & 94 \\
\hline Average & 102 & 29 & 86 & 84 \\
\hline $\begin{array}{l}\text { Boiteux shadow } \\
\text { price }\end{array}$ & \multicolumn{3}{|c|}{58} & 50 \\
\hline \multicolumn{5}{|l|}{ In 2050} \\
\hline POLES & 319 & 85 & 682 & 130 \\
\hline GEMINI-E3 & 446 & 62 & 339 & 60 \\
\hline IMACLIM-R & 130 & 60 & 200 & 114 \\
\hline Average & 298 & 69 & 407 & 101 \\
\hline $\begin{array}{l}\text { Boiteux shadow } \\
\text { price }\end{array}$ & \multicolumn{3}{|c|}{104} & 74 \\
\hline
\end{tabular}

The 2009 study arrived at its proposals by synthesising these multiple elements of information and knowledge. It set a pivot value of EUR (2008) 100 per tonne of carbon for 2030, based essentially on a reasoned synthesis and critical analysis of the results generated by the various models. Hotelling's rule was not applied to the pre-2030 period, because it would have resulted in a rather high carbon value of EUR 45 in 2009, at odds with the value of EUR 26 adopted up to then and very far removed from the value given by the carbon allowances markets at the time, which was around EUR 20. A political consensus was reached on a value of EUR 32 per tonne of $\mathrm{CO}_{2}$. For the period after 2030, a trend following Hotelling's rule was adopted, i.e. a rate of increase of $4 \%$ (the discount rate at that time) up to 2050, at which date the value became EUR 200. It was recommended that sensitivity tests for that date be carried out at EUR 150 and EUR 300 . 
Figure 2. $\mathrm{CO}_{2}$ value recommended by the 2009 Quinet Commission

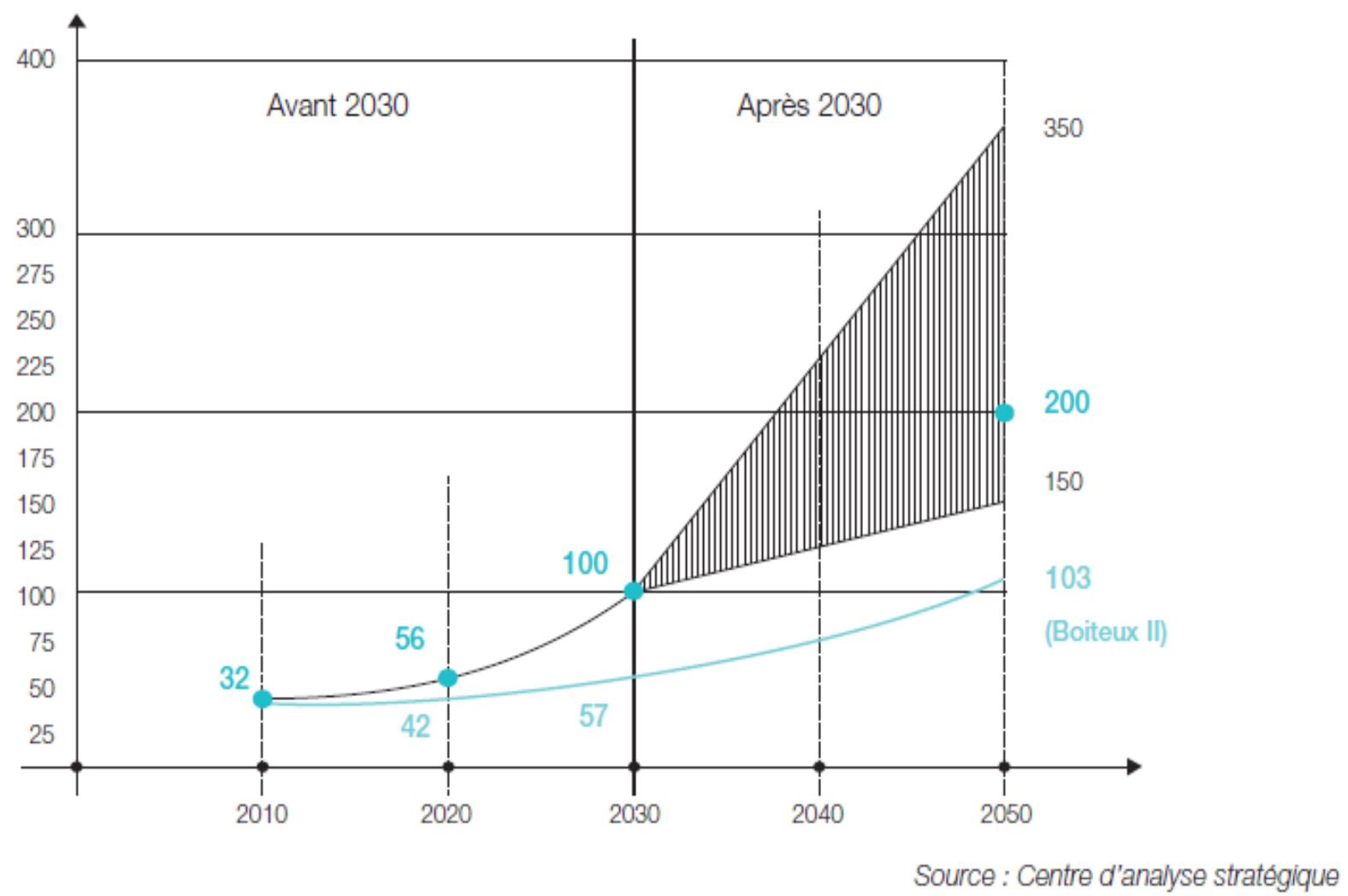

[Avant $2030=$ pre-2030; Après $2030=$ post-2030.]

\section{Revision of these provisions in 2013}

A repeat of the 2009 modelling exercises in 2012-13 might have been considered. However, little time has elapsed since the 2009 report, and repeating those exercises would have entailed more detailed definition or revision of the energy mix, which is a subject of debate in many countries. Several countries have decided to give up nuclear energy, and the proportion of non-renewable energy resources is now an issue, with well-known consequences for recourse to fossil fuels and the level of greenhouse gas emissions. The industrial exploitation of shale gas will have an ambiguous impact on global warming, depending on whether the forms of energy it replaces give rise to more emissions (coal) or fewer emissions. The place which electric vehicles will occupy is still unclear.

All of which led to the conclusion that a renewal of work on the carbon value, which would have involved long and laborious study, was incompatible with the deadlines set for the working party's deliberations, although such a study was worth conducting in the relatively near future. It was therefore decided simply to make marginal adjustments taking account of the new economic data and the change in the discount system.

The figure of EUR (2008) 100 for the 2030 pivot value has not been changed: it was the subject of a consensus among stakeholders whose positions are very far apart, and it did 
not seem advisable to call that agreement in question, especially as the scientific foundations for that figure are still valid: they resulted from outputs of models which it had been decided not to call into question.

It then remained to establish the chronology of values for the years before and after 2030 on that basis. Since the trends established in the 2009 report were based on the discount rate, in accordance with Hotelling's rule, they had to be adjusted to the decisions taken concerning that rate: the new system comprises a risk-free rate of $2.5 \%$ and a risk premium of $2 \%$, and a variant consisting of a single rate of $4.5 \%$ (compared with $4 \%$ previously).

The adjustments are simpler in the case of the variant with a single rate of $4.5 \%$. It is known that, in a logic of the Hotelling type, an increase in the discount rate gives rise to an increase in the growth rate of the shadow price, which rises from $4 \%$ to $4.5 \%$. As a corollary, the initial value is reduced, and the far-distant time when the use of nonrenewable resources will cease is brought forward.

With the new discount system, comprising a risk premium and a risk-free rate, things are more complicated. One must first determine the beta coefficient to be applied to changes in greenhouse gas emissions. Very little is known about the value of that coefficient, for which two causalities present themselves, relating to the source of the uncertainties and the direction of the causalities. The following presentation is closely based on a working paper by Gollier (2012). The first causality puts the emphasis on the uncertainties relating to $\mathrm{CO}_{2}$ emissions and their consequences in terms of damage. According to that approach, a reduction in $\mathrm{CO}_{2}$ emissions has a positive impact on GDP, the correlation between the two is negative, and so, consequently, is the beta coefficient. In the case of the inverse causality, the uncertainties essentially relate to GDP: a reduction in GDP leads to a reduction in emissions, the correlation between the two is positive, and so is the beta coefficient.

Which of these two causalities is preferable? There are few proofs available. The tests performed by Gollier in the above-mentioned paper, simulating the combined effect of the two uncertainties with probability ranges for each of them, speak in favour of a positive beta of 1 to 2 . Those are the values which best reflect the correlation between trends in the social cost of carbon and GDP trends. Bearing in mind the opinions that exist in favour of a negative beta coefficient, a beta of 1 has been adopted. The meaning of this parameter must be clearly understood: it must be used when the aim is to discount a surplus variation resulting from a change in greenhouse gas emissions for a future year. The corresponding rate is given by $r_{f}+1 * \varphi=0.025+1 * 0.02=0.045$.

In the case of an investment which has the effect of generating a saving of $x_{t}$ tonnes of $\mathrm{CO}_{2}$ in future year $t$, it is necessary to factor in the uncertainty relating to the $x_{t}$ quantities, and hence apply a coefficient of $\beta_{x}$ to the quantities, translating the correlation between the economised $x_{t}$ quantities and GDP.

Finally, to calculate a surplus variation, one needs to know the shadow price of a tonne of $\mathrm{CO}_{2}$ at time $\mathrm{t}$, i.e. the relative price trend of carbon. In the previous procedure where uncertainty was not factored in and there was a single discount rate, the shadow price at year $t$ was determined by taking the shadow price for the base year - here, EUR 100 in 2030 - and applying to it a growth rate equal to the discount rate in accordance with Hotelling's rule. The result of this procedure was that the discounted value of a tonne of carbon was the same irrespective of the year in which it was emitted. Demonstration of that result is based on the idea that, if it were not verified, the total discounted social 
value of the deposit, and hence total welfare, could be increased by means of intertemporal trade-offs.

Subject to more detailed analysis, it appeared that the same reasoning applies where risk is integrated in the rate, and that the growth rate of the carbon price has to be equal to its own risk-related discount rate, i.e., as we saw previously, $4.5 \%$.

What are the consequences for the trend of the shadow price of carbon, starting from a value of EUR 100 for the pivot year 2030?

This rule would normally have led to a reduction of the 2010 value. Other factors also speak in favour of that option: the economic crisis has made it easier to meet international commitments, and the prices delivered by the allocations market have fallen considerably. On the other hand, the level chosen for the shadow price in 2009 was possibly a little too low; the signals from the allocations market are unreliable, owing, among other things, to the dysfunctions of that market; and a proposal to reduce the carbon value would have given the wrong signal to public opinion and political decisionmakers, especially as the latest IPCC studies confirm that global warming is accelerating. For those reasons, it was decided to retain the 2010 value and the assumption of growth from 2010 to 2030 . However, the growth rate of $4.5 \%$ per annum was adopted for the period 2030-70, whereas the value assigned in the previous provisions applied only up to 2050.

It is hardly necessary to mention or emphasise the numerous uncertainties affecting these assumptions, whether technological (date of exhaustion of non-renewal energy resources, total volume of exploitable deposits, size of damages caused by emissions, possibilities of $\mathrm{CO}_{2}$ absorption, etc.) or political (national energy policies, international agreements, pricing of non-renewal energy resources, etc.). It must also be borne in mind that the justification for applying Hotelling's rule to determine the growth of the carbon price assumes a first-best economic situation, which is by no means the case. Normally the price of carbon, as well as its trend, should be deduced from the long-term strategies and reference scenarios, which will include many other clauses and provisions than those resulting from a first-best situation. This point is brought out clearly in the paper by Rozenberg, Vogt-Schilb and Hallegatte (2013).

\subsection{Biodiversity}

Biodiversity covers a set of complex qualities and characteristics that are neither clearly defined nor fully explored, and are moreover very specific to local situations. What can an expanse of ordinary grassland, a wetland ecosystem and a forest have in common?

For that reason, the attribution of an economic value to biodiversity runs into many difficulties. Of course, the ideal would be to have available values that enable us to factor in the multiple forms of damage to biodiversity caused by transport infrastructures, both through their construction and through the uses made of them and the impacts generated by their use, such as the impact of induced urbanisation. In the meantime, concern with biodiversity translates into commitments and regulatory constraints such the "no net loss" policy (no increase in land artificialisation) or the "avoid-reduce-offset" rule.

Numerous studies in France and abroad have aimed at estimating the economic value of biodiversity and its ecosystem services. In France, the Chevassus-au-Louis report (2009), which reviewed the state of scientific knowledge and proposed a methodological 
framework for estimating the economic value of biodiversity, was a significant step forward. ${ }^{14}$ Among the components of the total economic value (TEV) of biodiversity, the report puts the emphasis on the use values of ordinary biodiversity. As a methodology test, the authors put forward a calculation of the values of a number of ecosystem services which are produced by the ordinary biodiversity of two types of environment (temperate forests and permanent grassland) and are of benefit to society.

The work which followed that report aimed at adding bricks to the TEV estimate by incorporating the non-use value of biodiversity using combined analysis techniques (Commissariat Général au Développement Durable, 2011, in particular).

It seems nonetheless that the biodiversity values calculated in these reports are minimum values which represent only part of the range of ecosystem services generated by the ecosystems in question. In the present state of knowledge, they seemed too patchy and insufficiently robust for use in socio-economic calculation.

Pending the possible future establishment of reference values recognised by the various parties involved in territorial management, the "avoid, reduce and offset" principle is adopted to take account of biodiversity targets, not by evaluating the cost of biodiversity reductions generated by infrastructure but by incorporating the cost of realising the supplementary inputs needed in order to maintain the previous level of biodiversity, and by providing, at each stage in the study of the project where such cost arises, an idea of how accurately it is determined.

The situation is clearly unsatisfactory, however, inasmuch as application of that principle involves numerous decisions of a subjective nature that would need to be informed by economic calculation. At the present time, pending the progress ardently awaited, it can be used only as a framework, by applying the minimum values drawn from the abovementioned studies or hinge values such as: "if such and such a decision is taken to conserve biodiversity, it means that its value is at least..."

\subsection{Value of agricultural land}

A debate is emerging in France, instigated by stakeholders such as farmers' associations and environmental groups, concerning the value assigned to agricultural land, which is currently estimated by its market value. Whether market value accurately reflects the value of agricultural land to the community is questionable.

As the Food and Agriculture Organization (FAO) points out (1999), ${ }^{15}$ agriculture performs a number of different functions for society: a food function, an economic function and a social function.

The multifunctional character of agricultural land thus refers to numerous goods and services which, except for basic agricultural products, are not traded on the market because they are public assets or externalities. A relatively abundant literature has been devoted to their analysis, in particular by the OECD in the early 2000s, but has not produced any integrated estimates of the collective value of agricultural land. Its collective value should reflect this whole set of functions, which correspond by and large to the gain by the farmer, corrected by the amount of subsidies granted, plus the net value of ecosystem services rendered by the agricultural area (positive externalities relating to agricultural biodiversity, and negative externalities, including pollution, erosion, etc.), and the value of the food function (food security and independence) - all of which must be seen from a prospective viewpoint, incorporating long-term prospects. 


\section{FLOW EFFECTS}

\subsection{Pollution}

The methods applied in France at the present time were introduced in the early 2000s. They are based essentially on top-down procedures in which a total cost of pollution at national level is distributed among vehicle types. The procedures involved were revised, largely in the light of European studies conducted in the framework of the ExternE project series (2005), the CAFE programme (2005) and the HEATCO programme (2006), which brought significant advances in the modelling of pollutant emissions, their effects on health and the environment, and the monetarisation of those effects. Those studies were based on impact pathway methodology, a bottom-up approach originally developed in the ExternE project series, then taken over and improved in subsequent projects. The results fed into studies of a more sectoral nature such as the Handbook of external costs in the transport sector (2008) and the report by CE Delft/INFRAS (2011), aimed at devising reference monetary values for socio-economic calculation in the transport sector.

The revision of French procedures started from the values proposed in the 2008 Handbook, with some adjustments to French conditions to take account of the proposed increase in human life value, which rose from EUR 1.5 million to EUR 3 million; as a corollary, the life-year value of EUR 46000 adopted in the Handbook was raised to EUR 115000 for France. Account was also taken of the fact that the values in the Handbook were essentially based on German conditions, whereas vehicle types and density are very different in France.

Table 6 sets out, by way of example, the recommended values for road transport.

Table 6. Shadow values for road transport (combustion and wear emissions)

\begin{tabular}{l|c|c|c|c|c}
\hline $\begin{array}{c}\text { EUR (2010) per } \\
\mathbf{1 0 0} \mathbf{v - k m}\end{array}$ & $\begin{array}{c}\text { Very } \\
\text { dense } \\
\text { urban }\end{array}$ & $\begin{array}{c}\text { Dense } \\
\text { urban }\end{array}$ & Urban & $\begin{array}{c}\text { Diffuse } \\
\text { urban }\end{array}$ & Interurban \\
\hline Passenger car & 11.1 & 3.1 & 1.3 & 1.0 & 0.9 \\
\hline Pass. car diesel & 13.8 & 3.8 & 1.6 & 1.3 & 1.0 \\
\hline Pass. car petrol & 4.5 & 1.3 & 0.6 & 0.5 & 0.5 \\
\hline Pass. car LPG & 3.5 & 1.0 & 0.4 & 0.3 & 0.1 \\
\hline LGV & 22.0 & 6.1 & 2.5 & 1.9 & 1.5 \\
\hline LGV diesel & 22.9 & 6.3 & 2.6 & 2.0 & 1.6 \\
\hline LGV petrol & 6.3 & 1.9 & 0.9 & 0.8 & 0.8 \\
\hline HGV diesel & 186.6 & 37.0 & 17.7 & 9.4 & 6.4 \\
\hline Motorcycle & 8.7 & 2.5 & 1.0 & 0.8 & 0.5 \\
\hline PSV & 125.4 & 24.8 & 11.9 & 6.3 & 4.2 \\
\hline
\end{tabular}

Source: Centre d'analyse stratégique. 
With regard to the trend in these values, an annual reduction of $6 \%$ over the period 2010-20 related to vehicle development seems to take due account of observed or foreseeable technological improvements. Since there are fewer studies of possible trends for the air and rail modes, it is recommended to model the related pollution emissions trend on the consumption trend, while incorporating a technical progress factor to be determined. The trend in pollution by public transport remains in need of detailed investigation, especially as present studies do not take account of the health effects resulting from the propagation of microbes and viruses in public transport, a subject to which too little attention has been paid so far.

\subsection{Upstream/downstreameffects}

Upstream/downstream effects comprise disamenities related to: energy production and distribution (well-to-tank emissions); vehicle manufacture, maintenance and disposal; and infrastructure construction, maintenance and end-of-life.

The 2008 Handbook and the CE Delft INFRAS report propose reference values centred on emissions of atmospheric pollutants and greenhouse gases during energy production and distribution (upstream externalities), namely:

- atmospheric pollution due to well-to-tank emissions of PM10, PM2.5, $\mathrm{NO}_{\mathrm{x}}, \mathrm{SO}_{2}$ and NMVOC;

- climate change due to well-to-tank emissions of greenhouse gases $\left(\mathrm{CO}_{2}, \mathrm{~N}_{2} \mathrm{O}\right.$ and $\mathrm{CH}_{4}$ ).

These values have been adjusted to take account, as in the case of pollution, of the values of a life-year and a tonne of $\mathrm{CO}_{2}$ recommended in the present report, i.e.:

- a life-year valued at EUR (2010) 115 000, instead of EUR (2010) 46 000;

- a tonne of $\mathrm{CO}_{2}$ valued at EUR (2010) 32, instead of EUR (2010) 146.

The recommended values for road, rail, air and inland waterways are shown in the following table. 
Table 7. Recommended shadow values for upstream and downstream traffic effects

\begin{tabular}{l|c}
\hline $\begin{array}{c}\text { EUR (2010) per } \\
\mathbf{1 0 0} \mathbf{~ v - k m}\end{array}$ & $\begin{array}{c}\text { Shadow values for atmospheric emissions } \\
\text { from upstream processes }\end{array}$ \\
\hline \multicolumn{2}{c}{ Road transport } \\
\hline Passenger car & 0.90 \\
\hline PSV & 2.83 \\
\hline Motorcycle & 0.42 \\
\hline HGV & 2.96 \\
\hline LGV & 1.14 \\
\hline \multicolumn{2}{|c}{ Rail transport } \\
\hline Electric passenger train & 25.64 \\
\hline Diesel passenger train & 136.35 \\
\hline Electric goods train & 30.50 \\
\hline Diesel goods train & 143.51 \\
\hline \multicolumn{2}{c}{ Air transport } \\
\hline Aeroplane & 58.38 \\
\hline \multicolumn{2}{c}{ Inland waterway transport } \\
\hline Inland waterway & 96.61 \\
\hline
\end{tabular}

Source: Centre d'analyse stratégique.

\subsection{Noise}

The procedure for factoring noise into project appraisal was based hitherto on analysis of the average rental value of living accommodation, which consists in identifying the dwellings subjected to noise and deducing therefrom a loss in dwelling value that represents the cost of the noise. This method is precise but requires very detailed information which is generally unavailable at the preliminary levels at which cost-benefit analysis is conducted. For that reason, the study of noise impacts was often missing from economic evaluation exercises.

The new recommendations therefore propose two alternative procedures: one similar to the previous procedure, requiring a great deal of information, and a more summary procedure based on noise disamenities per vehicle-kilometre. The latter costs are taken from the 2008 Handbook and, like the costs of pollution and upstream/downstream effects, adjusted to French conditions. These values per vehicle-kilometre, however, are not simple to use. They relate to situations of average noise protection in which no special anti-noise measures are in force, and thus give a crude measure that takes no account of adjustments to a project's technical provisions. They must therefore be used with discretion and not applied automatically. 


\section{OVERVIEW: CHANGES IN THE DISTRIBUTION OF BENEFITS}

The consequences of the changes outlined above were simulated by applying the old and new procedures to a number of typical projects. Overall, the share of pollution in the end result increases significantly, by a factor of 1.5 to 3 depending on the project, but remains small, no more than a few percentage points. The introduction of upstream/downstream effects also accounts for only a few percentage points, and the same is true of noise effects. While all these flow effects carry greater weight than in the previous procedures, they still have only a limited impact on overall benefits.

Biodiversity is not incorporated in the cost-benefit analyses. It appears only in construction costs, in compliance with the avoid-reduce-offset rule, and can sometimes account for a significant proportion of costs, of the order of several dozen percentage points.

Owing to the increase in the discount rate and the longer evaluation period, effects related to $\mathrm{CO}_{2}$ emissions, which previously had a negligible impact, may now represent $10 \%$ to $20 \%$ of the benefits in certain projects.

The introduction of a new discount system has no appreciable effect on project implementation dates. On the other hand, the beta coefficients lead to differentiation of inter-modal projects and marginal changes to their hierarchical ordering.

It is nevertheless certain that the biggest consequences of the new procedures are expected to come from the long-term strategy and the reference scenarios for its implementation, as seen from the simulations, which show that the economic profitability indicators for a given project are particularly sensitive to traffic growth and the related prices trends, and to discount rates. 


\section{NOTES}

1. Boiteux Report I (1994), "Transports: pour un meilleur choix des investissements", Commissariat général du Plan.

2. Boiteux Report II (2001), "Transports: choix des investissements et coûts des nuisances", Commissariat général du Plan, Paris, La Documentation française.

3. Lebègue Report (2005), "Le prix du temps et la décision publique", Commissariat général du Plan.

4. Quinet Report (2008), "La valeur tutélaire du carbone", Centre d'analyse stratégique, Paris, La Documentation française.

5. Chevassus-au-Louis Report (2009), "Approche économique de la biodiversité et des services liés aux écosystèmes", Centre d'analyse stratégique, Paris, La Documentation française.

6. Gollier Report (2011), "Le calcul du risque dans les investissements publics", Centre d'analyse stratégique, Paris, La Documentation française.

7. "Evaluation socio-économique des investissements publics", Commissariat général à la stratégie et la prospective, Paris, to be published by La Documentation française (2012); report of the commission chaired by É. Quinet.

8. If the project entailed no systemic risk, a benefit $a(t)$ at year $t$ would currently be worth: $a(t) /(1+r f) t$, where $r f$ is the risk-free rate. Where the project entails a systemic risk whose correlation with economic activity is measured by $\beta$, the benefits at year $\mathrm{t}$ are reduced to $\mathrm{a}(\mathrm{t}) /(1+\beta \varphi) \mathrm{t}$ and their discounted value at year 0 is: $[a(t) /(1+\beta \varphi) t] /(1+r f) t$, which is roughly equivalent to $a(t) /(1+\beta \varphi+r f) t$ : it all works out as if the applicable discount rate were $r=r f+\varphi \beta$, which is called the riskrelated rate and is project-dependent with regard to $\beta \varphi$.

9. This formula comprises a separable subjacent intertemporal utility function in which each year's utility has the form: $-\frac{U^{1-\gamma}}{1-\gamma}$. But other utility functions could be envisaged.

10. Independence of benefits with respect to date of project completion, absence of decrease of benefits over time. Where the boost in benefits begins when the project is put into service, the rule is slightly modified but its sense is unchanged: the firstyear benefit must be replaced by an amount weighted by the benefits of the years when the boost takes place. Moreover, in a situation of budget restrictions, the methods described below in the corresponding section must be applied. 
11. See note by B. Lapeyre and É. Quinet annexed to the report "Evaluation socioéconomique des investissements publics".

12. From 1990 levels in each case.

13. Centre d'analyse stratégique (2009), La valeur tutélaire du carbone. Commission chaired by Alain Quinet.

14. It should be noted that the "Chevassus-au-Louis" method is similar to that developed in the international TEEB study (2008).

15. FAO, 1999. Cultivating Our Futures, "Issues Paper: The Multifunctional Character of Agriculture and Land", http://www.fao.org/docrep/x2777f/X2777F03.htm. 


\section{BIBLIOGRAPHY}

ADEME (2012), Contribution de I'ADEME à l'élaboration de visions énergétiques 2030-2050.

Blaney, S., A. Hickford and J. Preston (2013), Planning Transport Networks for an Uncertain Future: A UK Case Study, communication to the 2013 European Transport Conference.

Boiteux, M. (1994), Transports : pour un meilleur choix des investissements, Commissariat général du Plan.

Boiteux M (2001), Transports : choix des investissements et coûts des nuisances, Commissariat général du Plan, Paris, La Documentation française.

Château, B., V. Bagard, Y. Crozet, H.G. Lopez-Ruiz (2008), « Comment satisfaire les objectifs internationaux de la France en termes d'émissions de gaz à effet de serre et de pollution transfrontière » ENERDATA Report, Prédit, Paris.

CE Delft-INFRAS (2011), External Costs of Transport in Europe - Update Study for 2008, November, $163 \mathrm{pp}$.

CGDD (Commissariat général au développement durable) (2011), Évaluation économique des services rendus par les zones humides - Enseignements méthodologiques de monétarisation, $220 \mathrm{pp}$.

Chevassus-au-Louis, B. (2009), Approche économique de la biodiversité et des services liés aux écosystèmes, Centre d'analyse stratégique, Paris, La Documentation française.

CAFÉ (2005a), M. Holland (EMRC), S. Pye, P. Watkiss (AEA Technology),

B. Droste-Franke, P. Bickel (IER), Clean Air for Europe Programme (CAFE):

Damages per tonne of PM2.5, NH3, SO2, NOx and VOC's of EU-25 Member State (excluding Cyprus) and surrounding seas (Marginal damage cost report) Didcot (UK): AEA Technology Environment.

CAFÉ (2005b), F. Hurley, A. Hunt, H. Cowie, M. Holland, B. Miller, S. Pye, P. Watkiss, Clean air for Europe programme (CAFE): Methodology for the Cost-Benefit analysis for CAFÉ Volume 2: Health Impact Assessment Didcot (UK): AEA Technology Environment, 2005.

European Commission/2001, $\operatorname{COM(2001)~370,~White~Paper,~European~transport~policy~for~}$ 2010: time to decide.

European Commission Brussels, 2011 COM (2011), 144 final White Paper, Roadmap to a Single European Transport Area - Towards a competitive and resource efficient transport system". 
European Communities (2008), TEEB, The Economy of Ecosystems and Biodiversity, interim report.

ExternE (2005), P. Bickel, R. Friedrich (Eds.): Externalities of Energy, Methodology, 2005 update Luxembourg: European Commission.

FAO (1999), Cultivating Our Futures - Multiples fonctions de l'agriculture et des terres : I'analyse : http://www.fao.org/docrep/x2777f/X2777F03.htm

Gollier, C. (2011), Le calcul du risque dans les investissements publics, Centre d'analyse stratégique, Paris, La Documentation française.

Gollier, C., (2013), Evaluation of long-dated investments under uncertain growth trend, volatility and catastrophes, Toulouse School of Economics, unpublished manuscript.

European Commission (2008), Handbook on Estimation of External Costs in the Transport Sector; produced within the study on Internalisation Measures and Policies for All External Costs of Transport (IMPACT) 2008, Version1.1, Delft.

HEATCO (2006), General issues in costing analysis: Units of account, base years, and currency conversion, Annex B to HEATCO Deliverable 5, Developing Harmonised European Approaches for Transport Costing and Project Assessment.

Lapeyre, B. et E. Quinet (2013), Choix des investissements avec prise en compte du risque systèmique, Annex to Quinet 2013.

Lebègue, D. (2005), Le prix du temps et la décision publique, Commissariat général du Plan.

Quinet, A. (2008), La valeur tutélaire du carbone, Centre d'analyse stratégique, Paris, La Documentation française.

Quinet, A. et E. Quinet (2012), La gouvernance des projets d'infrastructure de transports, Revue Transport, February.

Quinet, E. (2013), Évaluation socio-économique des investissements publics, Commissariat général à la Stratégie et la Prospective, Paris, to be published 2014, La Documentation française.

Rozenberg, J., A. Vogt-Schilb and S. Hallegatte (2013), How Capital-Based Instruments Facilitate the Transition Toward a Low-Carbon Economy, The World Bank Policy Research Working Paper. 
